\title{
TEKNOLOGI TEPAT GUNA “MEKUTUS" GUNA MENGURANGI RESIKO PEMASAKAN TELUR ASIN
}

\author{
Hardo Wahyudi ${ }^{1}$, Nurleila Jum'ati ${ }^{2}$, Nurul Aini ${ }^{2}$ \\ ${ }^{1,2,3}$ Universitas Wijaya Putra
}

hardowahyudi@uwp.ac.id,nurleila@uwp.ac.id, ainiarsenal@yahoo.com

\begin{abstract}
Abstract: SMEs engaged in the duck livestock and salted eggs field use conventional tools for steaming salted eggs. The salted egg steaming using conventional tools needs 4 hours in steaming 450 eggs with rupture or cracking risk reaching $20 \%$ or 90 eggs in each production process. Thus, SME partners needs a steaming tool that able to solve the problem. It is MEKUTUS. This tool consists of boiler room, egg room and circulation room. To maintain the temperature not exceed specified limit, $70^{\circ} \mathrm{C}-90^{\circ} \mathrm{C}$, MEKUTUS is completed with temperature controller automation. It is the digital temperature controller as its input and the smoke exhaust as output. The result of steaming process becomes faster. It becomes 2 hours and the risk of egg rupture, breaking or cracking can be minimized. The percentage decrement of loss reach $173.6 \%$ per month. With the efficiency of time, effort and cost of production, it makes partner productivity increase. As such, it needs viral marketing further through social media to expand the market. Thus, SME partners can increase their income in steaming salted egg selling.
\end{abstract}

Keywords: MEKUTUS, Automation, Steaming, viral marketing

\begin{abstract}
ABSTRAK
Abstrak : UKM yang bergerak di bidang ternak bebek dan produsen telur asin mempergunakan alat konvensional untuk pengukusan telur asin. Pengukusan telur asin dengan alat konvensional membutuhkan waktu 4 jam untuk mengukus 450 butir dengan resiko pecah dan atau retak mencapai $20 \%$ atau 90 butir setiap kali proses produksi. Dengan demikian, mitra UKM membutuhkan alat pengukus yang dapat menyelesaikan permasalahan tersebut yaitu MEKUTUS. Alat ini terdiri dari ruang boiler, ruang telur dan ruang sirkulasi. Untuk menjaga agar suhu tidak melebihi batas yang sudah ditentukan yakni $70^{\circ} \mathrm{C}-90^{\circ} \mathrm{C}$ maka alat ini dilengkapi dengan otomasi pengontrol suhu yaitu digital temperature controller sebagai masukannya dan cerobong pembuangan asap sebagai output. Hasilnya proses pengukusan menjadi lebih cepat menjadi 2 jam dan resiko pecah atau retak pada telur dapat terminimalisir. Penurunan prosentase kerugian mencapai 173,6 \% per bulan. Dengan efisiensi waktu, tenaga dan biaya produksi membuat produktivitas mitra semakin meningkat sehingga diperlukan viral marketing melalui media sosial untuk meluaskan pasar. Dengan demikian mitra UKM dapat meningkatkan omzet penjualan telur asin kukus.
\end{abstract}

Kata Kunci : MEKUTUS, Otomasi, Pengukusan, viral marketing 


\section{PENDAHULUAN}

UKM yang bergerak di ternak bebek dan produsen telur asin. Salah satu metode pemasakan telur asin yakni dengan cara pengukusan.

Proses pengukusan menggunakan alat konvensional (gambar 1) yaitu dandang atau panci kukusan dan kompor $L P G$ yang membutuhkan waktu sekitar 4 jam untuk mengukus 450 butir sehingga terjadi penumpukan telur karena tidak adanya pembatas antar telur maka tumpukan telur pada bagian paling bawah akan menahan beban dari telur diatasnya sekaligus mendapat tekanan yang sangat tinggi dari kalor uap sehingga resiko pecah dan atau retak mencapai sekitar $20 \%$ yaitu sekitar 90 butir telur setiap kali proses produksi, sedangkan dalam sehari mitra UKM harus memenuhi kebutuhan pasar antara 700 - 1500 butir telur per harinya tergantung week day atau week end.

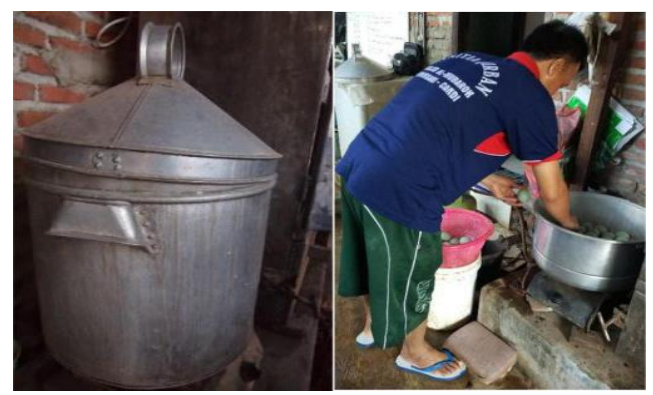

Gambar 1. Panci Pengukus (alat konvesional)

Berdasarkan dari observasi dan wawancara didapatkan data seperti tabel 1 di bawah ini. Dari tabel 1 dapat disimpulkan bahwa permasalahan yang dihadapi oleh mitra UKM adalah pemasakan telur asin kukus dan pemasaran.

Tabel 1. Rekapitulasi Data Observasi dan Wawancara

\begin{tabular}{llll}
\hline No & Temuan Data & \multicolumn{2}{c}{ Keterangan } \\
\hline 1. & Bahan baku & Telur bebek & $\begin{array}{l}\text { Hasil ternak sendiri } \\
\text { Beli di peternak } \\
\text { dalam satu } \\
\text { kelompok }\end{array}$ \\
2. Bahan & Genunjang & bata halus & Membeli \\
& LPG & Membeli \\
Telur asin & Asap & $\begin{array}{l}\text { Mampu memenuhi } \\
\text { pesanan }\end{array}$ \\
3. Produksi & Telur asin & Mampu memenuhi \\
& & oven & pesanan
\end{tabular}

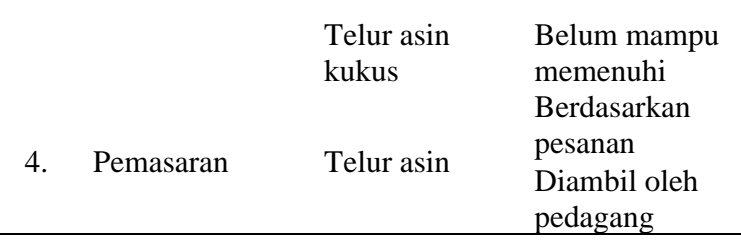

Dengan demikian mitra membutuhkan alat pengukus yang dapat mempersingkat waktu proses pengukusan dan mengurangi tingkat resiko pecah dan atau retak pada telur serta menghemat biaya untuk bahan bakar. Dengan efisien waktu dan tingkat resiko yang lebih rendah maka mitra UKM dapat memenuhi kebutuhan permintaan pasar setiap harinya. Dengan meningkatnya kualitas dan kuantitas pada telur asin, membutuhkan metode tambahan selain metode yang sudah dilakukan selama ini, yaitu dengan viral marketing melalui media sosial untuk metode pemasaran.

\section{METODE}

Adapun rangkaian metodologi pelaksanaan adalah sebagai berikut :

Penggumpulan Data : Pada tahap ini merupakan proses metode pengumpulan data melalui pengamatan langsung atau peninjauan secara cermat dan langsung di lapangan atau lokasi penelitian guna memperoleh data-data yang rill. Observasi kami ke UD Do'a Bunda Sidoarjo Jawa Timur memperoleh fakta tentang permasalahan produktivitas pengukusan telur asin. Penggumpulan data dilakukan di mitra UKM, dan diperoleh hasil : permasalahan pengukusan telur asin, produktivitas dan omset mitra dengan menggunakan sistem konvensional.

Study Literature : Study literature berisikan serangkaian kegiatan pencarian sumber-sumber yang relevan dan terpercaya guna memperoleh materi dan acuan dalam penulisan kegiatan ini. Tujuan dari study literatur adalah memperoleh materi-materi penunjang yang melandasi pemecahan masalah, baik itu bersumber dari buku, website ataupun jurnal.

Mendesain Alat : Desain alat menggunakan software solid works untuk menggambarkan sketsa mesin kukus telur asin yang akan dibuat. Desain tersebut disertai detail ukuran dan bahan serta digambar dengan berbagai sudut pandang sehingga dapat dilihat secara rinci ukuran yang dipakai dalam pembuatan mesin kukus telur asin.

$$
\text { Ekonomi, Sosial, dan Budaya }
$$


Perancangan dan Pembuatan Alat :

Pada tahapan ini perancangan awal dilakukan. Data yang diperoleh dari study literature dan survey dipadukan untuk perancangan dan pembuatan. Dimana nantinya Teknologi Tepat guna ini diharapkan dapat menguntungkan bagi penggunanya pada khususnya dapat mengurangi tingkat resiko pecah pada telur dan mempercepat proses penggukusan sehingga mitra kerja kami dapat memenuhi kebutuhan pasar tanpa mengurangi kualitas produk yang di hasilkan. Perancangan alat berdasarkan kebutuhan pada mitra yaitu membagi kalor secara merata sehingga telur matang secara bersamaan dengan memberi saringan. Pemasangan cerobong pembuangan yang berfungsi mengeluarkan tekanan yang terjadi diruang pemasak telur dan memasang otomasi yang akan mengatur besar kecilnya api pada kompor. Pengontrol suhu digunakan untuk menjaga suhu didalam mesin tetap konstan.

Pengujian Alat : Pada metode ini dimaksudkan untuk memastikam bahwa kinerja masing-masing komponen teknlogi tepat guna mesin kukus telur asin dapat berfungsi optimal .Untuk proses pengujian dilakukan melalui percobaan lapangan yaitu di mitra pengabdian dengan pencatatatn data sehingga mempermudah dalam meganalisa perbaikan selanjutnya.

Evaluasi dan penyempurnaan alat : Pada metode evaluasi, hasil evaluasi pada saat pengujian digunakan sebagai acuan untuk penyempurnaan alat, sehingga dalam proses penyempurnaan alat ini berdasarkan data yang akurat.

Implementasi dan pendampingan penggunaan alat : Pendampingan kepada mitra UKM untuk penggunaan dan perawatan alat secara tepat. Tahap perawatan dan penggunaan alat dengan membuatkan buku panduan dan SOP.

Pendampingan dan penggunaan viral marketing : Pembuatan buku panduan penggunaan viral marketing. Pendampingan dalam proses pembuatan beberapa akun media sosial (e-mail, blog, facebook, instagram).

\section{HASIL DAN PEMBAHASAN Waktu dan Tempat Pelaksanan}

Program pengabdian ini dilaksanakan di Pengerajin Telur Asin dan Peternak bebek milik Bapak Musholin yang terletak di Desa Kebonsari Kecamatan Candi Kabupaten Sidoarjo dengan waktu pelaksanaan pengabdian selama 5 bulan.

\section{Perancangan dan pembuatan MEKUTUS (Mesin} $\underline{\text { Kukus Telur Asin) }}$

Desain mesin kukus telur asin seperti kebutuhan dari mitra UKM sebagai solusi dari permasalahan yang ada menggunakan software solid sebagimana yang tertera pada gambar 2 .

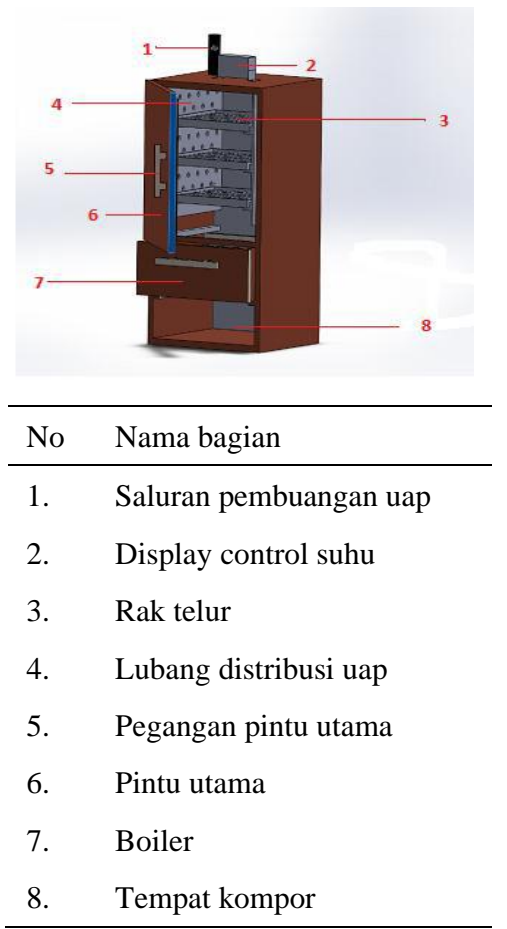

Gambar 2. Desain Mesin Kukus Telur Asin

Tabel 2. Bagian-bagian Mesin Telur Asin Kukus 
Mesin MEKUTUS (gambar 2) dirancang terbuat dari plat stainlees tebal $2 \mathrm{~mm}$, dengan dimensi $50 \mathrm{~cm} \quad \mathrm{x} \quad 58 \mathrm{~cm} \quad \mathrm{x} \quad 105 \mathrm{~cm}$. Untuk menghindari penumpukan maka dirancacang rak telur terbuat dari bahan besi stainless dengan diameter $4 \mathrm{~mm}$ panjang $45 \mathrm{~cm} \times 45 \mathrm{~cm}$ dengan kapasistas 300 butir. Bahan stainlesssteel sebagai konduktor yang baik menyebabkan proses pengukusan semakin cepat sehingga produktivitas lebih efektif dan efisien. Selain itu Hygienitas produk diperoleh karena mesin yang memakai bahan stainless steel dari sisi tampilan terlihat bersih dan cara perawatan yang sangat mudah. Dengan demikian proses produksi dapat dikatakan sangatbaik dan juga keamanan mesin ini dari permukaan luar tidak terlalu panas karena ada lapisan isolator didalamnya.Mesin juga dilengkapi dengan penggunaan sistem kontrol suhu menggunakan IC mikrokontroler AT89S52 dengan masukan menggunakan sensor suhu LM 35D (Putra, 2002). Banyaknya telur yang dapat ditampung dalam satu kali produksi desain tempat untuk menaruh telur selama pengukusan dapat dengan aman tidak saling berbenturan dengan telur yang lain dan ketika ditarik keluar tetap di tempatnyaDengan adanya otomasi maka tenaga Pak Mussolin Mitra UD.Do'a Bunda dapat dipergunakan untuk mengerjakan hal yang lain.

Tabel 3. Spesifikasi Mesin Telur Asin Kukus

\begin{tabular}{cll}
\hline No & $\begin{array}{c}\text { Spesifikasi } \\
\text { Mesin }\end{array}$ & \multicolumn{1}{c}{ Keterangan } \\
\hline 1 & Dimensi & $(50 \times 58 \times 105)$ \\
2 & Kapasitas & 300 butir \\
3 & Bahan Bakar & LPG \\
\hline
\end{tabular}

Tabel 4. Uji Fungsi Komponen

\begin{tabular}{ccc}
\hline No & Unit & Keterangan \\
\hline 1 & Rangka Mesin & Baik \\
2 & Sistem Otomasi & Baik \\
\hline
\end{tabular}

Dalam program ini mesin menggunakan jenis konveksi paksaan dengan memisahkan antara ruang untuk mengukus telur dengan boiler dan memberi semacam saringan yang berfungsi mengatur pembagian kalor dari uap air sehingga kalor akan dibagi dari bawah-atas dan dari sisi kiri-kanan melalui lubang dengan diameter lubang yang ditata dan diperhitungkan antar rak

dengan tujuan agar kalor dari uap air masuk ke ruang pemasakan telur dengan merata sehingga tingkat kematangan dari semua telur di ruang pemasakan sama. Hal tersebut terjadi karena MEKUTUS memiliki otomasi (solenoid valve) pada aliran gas dari tabung $L P G$ ke kompor untuk mengatur nyala api yang akan membuka pada suhu $\leq$ $70^{\circ} \mathrm{C}$ dan menutup pada suhu $90^{\circ} \mathrm{C}$ pada ruang pemasak telur (Novia, 2011).

Perancangan Rangkaian Sensor Suhu dan Penguat Tegangan Sensor

Teknik otomasi adalah penggunaan mesin, sistem kontrol, dan teknologi informasi untuk optimisasi produksi dan pengiriman barang dan jasa. Otomasi hanya dilakukan jika hasilnya lebih cepat, lebih baik secara kuantitas danatau kualitas dibandingkan dengan penggunaan tenaga kerja manusia. Dalam dunia industri, otomasi merupakan lanjutan dari mekaisasi, dimana mekanisasi masih membutuhkan operator manusia selama mesin beroperasi atau membutuhkan bantuan tenaga otot manusia agar mampu bekerja. Otomasi mengurangi peran manusia dalam hal tersebut.

Solenoid valve merupakan katup yang dikendalikan dengan arus listrik baik AC maupun DC melalui kumparan / selenoida. Solenoid valve ini merupakan elemen kontrol yang paling sering digunakan dalam sistem fluida. Aliran gas akan mengalir dari tabung gas menuju kompor melalui solenoid valve yang akan membuka pada suhu $\leq 70^{\circ}$ $\mathrm{C}$ sehingga aliran gas akan mengalir melaui selang api besar dan menutup pada suhu $90^{\circ} \mathrm{C}$ sehingga api akan mengalir melalui selang aliran api kecil seperti pada gambar 3 . 
Gambar 3. Sistem Otomasi Mekutus

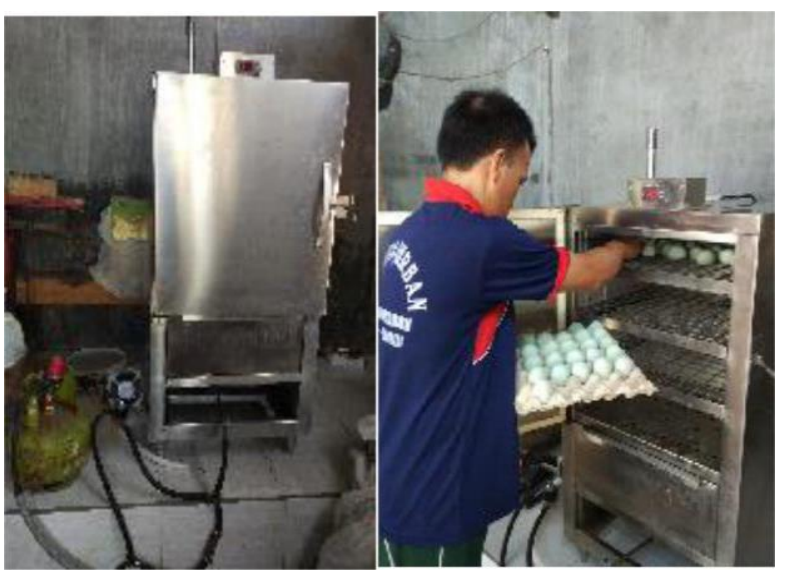

Tabel 5. Bagian-bagian Sistem Otomasi Mekutus

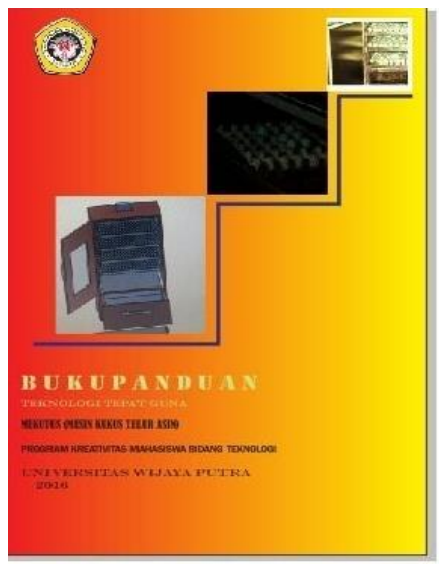

\section{Pelatihan dan Penggunaan MEKUTUS}

Mesin kukus telur asin (MEKUTUS) yang melalui proses manufaktur maka diserahkan pada

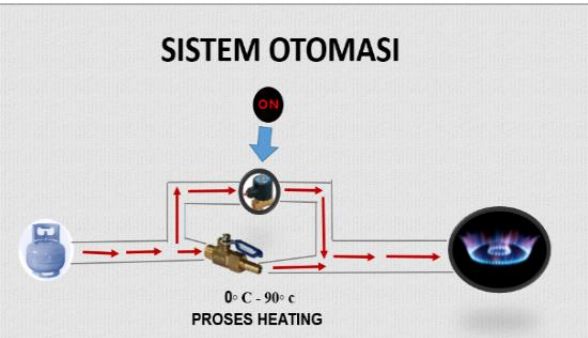

mitra UKM. Pada saat penyerahan dilakukan juga pelatihan dan sosialisasi tentang penggunaan dan perawatan MEKUTUS. Pada saat pelatihan pertama kali yakni uji coba tersebut terjadi efisiensi waktu pengukusan dari 4 jam menjadi 2 jam.

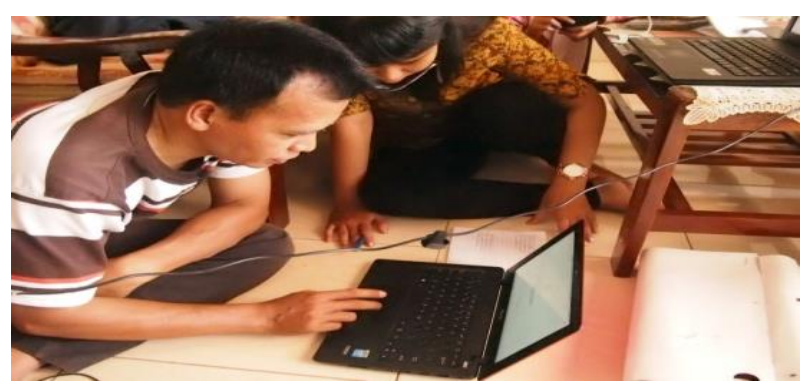

Gambar 4. Pelatihan Penggunaan Alat

Untuk keberlanjutan penggunaan dan perawatan bagi mitra UKM maka disiapkan buku panduan. Dengan buku panduan penggunaan dan perawatan tersebut maka mitra mempunyai pegangan ketika menghadapi kendala dalam penggunaan. MEKUTUS yang digunakan secara rutin pasti membutuhkan perawatan agar alat dapat awet dan terpakai dalam jangka waktu yang lama sebagaimana pada gambar 5 .

Gambar 5. Buku Panduan Penggunaan Mekutus

\section{Pelatihan dan Pendampingan Viral Marketing}

\begin{tabular}{cl}
\hline No & Nama bagian \\
\hline 1. & Tabung Gas \\
2. & Solenoid Valve \\
3. & Kran Api Kecil \\
4. & Digital Temperature \\
5. & Kompor \\
\hline
\end{tabular}

Ekonomi, Sosial, dan Budaya 
Dengan adanya peningkatan kualitas dan kuantitas telur asin kukus Mitra UKM maka untuk memperluas pemasaran dilakukan sosialisasi dan pendampingan viral marketing (Andini dkk, 2014). Berdasarkan account email, maka dikembangkan media sosial (account facebook) dan pembuatan blog. UKM mitra dibekali dengan modul aplikasi sederhana untuk mengoperasikan email, facebook dan blog yang tampak pada gambar 6 .

Pak Mussolin Mitra UD.Do'a Bunda dibantu dalam pembuatan email sebagai dasar untuk pembuatan media sosial - facebook - dan blog. dengan memperkenalkan produk telur asin asap di luar daerah Sidoarjo mengembangkan pemasaran telur asin. Dengan adanya viral maeketing maka Memotong panjangnya rantai distribusi dan promosi pada konsumen.

Adapun alamat media on line mitra sebagai berikut : 1). E-mail : Pakmusholin@gmail.com 2). Blog : Uddoabunda.blogspot.com 3). Facebook : uddoabunda

Gambar 6. Pelatiah dan PendampinganPenggunaan Viral Marketing

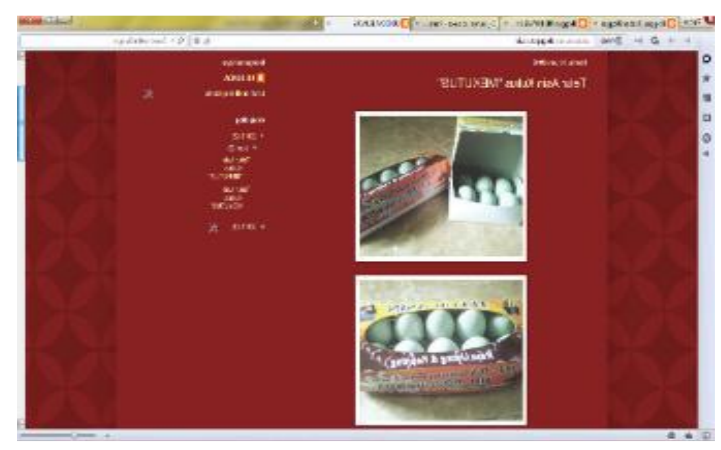

Gambar 7. Blog UD Do’a Bunda

Gambar 8. Facebook UD Do'a Bunda

Dengan viral marketing maka mitra UKM dapat meningkatkan pengembangan produktivitas yang berimbas dengan bertambahnya omzet dan penurunan prosentase kerugian $\mathbf{5 2 0 , 8 1 \%}$ dibandingkan dengan 3 bulan sebelum pemakaian MEKUTUS yang dibarengi dengan viral marketing

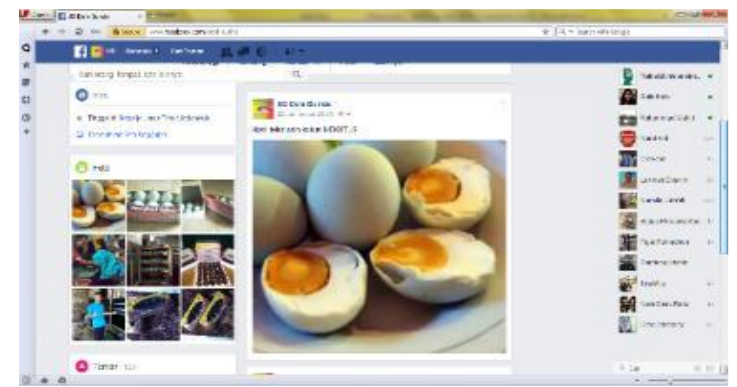

Manfaat yang dirasakan oleh mitra UD DOA BUNDA setelah memakai MEKUTUS adalah mengurangi resiko pecah dan retak telur pada proses pemasakan telur asin, mempercepat proses pemasakan telur asin, secara kuantitas dapat memenuhi kebutuhan pasar, menjaga kualitas gizi yang terkandung didalam telur, matang secara merata, penghematan bahan bakar dan meningkatkan omset penjualan.

Adapun perbandingan prosentase kerugian pada mitra sebelum menggunakan alat dan setelah menggunakan alat Mesin Kukus Telur Asin adalah sebagai berikut :

Tabel 5. Sebelum Menggunakan Mekutus

\begin{tabular}{lllll}
\hline Bulan & Jumlah & $\begin{array}{l}\text { Omzet telur } \\
\text { utuh }\end{array}$ & $\begin{array}{l}\text { Omzet telur } \\
\text { retak/pecah }\end{array}$ & Estimasi \\
\hline Feb & 31.000 & 86.800 .000 & 84.749 .000 & 2.051 .000 \\
Maret & 31.050 & 86.940 .000 & 84.919 .900 & 2.020 .100 \\
April & 32.050 & 89.740 .000 & 87.648 .900 & 2.091 .100 \\
Total & 94.100 & 263.480 .000 & 257.317 .800 & 6.162 .200 \\
\hline
\end{tabular}

Tabel 6. Setelah Menggunakan Mekutus

\begin{tabular}{lllll}
\hline Bulan & Jumlah & $\begin{array}{l}\text { Omzet telur } \\
\text { utuh }\end{array}$ & $\begin{array}{l}\text { Omzet telur } \\
\text { retak/pecah }\end{array}$ & Estimasi \\
\hline Mei & 32.950 & 92.260 .000 & 91.903 .300 & 356.700 \\
Juni & 34.250 & 95.900 .000 & 95.488 .900 & 411.100 \\
Juli & 34.700 & 97.160 .000 & 96.935 .200 & 224.800 \\
Total & 101.900 & 285.320 .000 & 284.327 .400 & 992.600 \\
\hline \multicolumn{5}{c}{ Berdasarkan perbandingan antara tabel 1.1 }
\end{tabular}

dan tabel 1.2 di atas maka didapatkan data bahwa terjadi penurun prosentase kerugian UD. Do'a Bunda setelah menggunakan alat Mekutus mencapai 520,81 $\%$ selama 3 bulan pemakaian Mekutus sehingga pendapatan mitra akan semakin meningkat.

$$
\text { Ekonomi, Sosial, dan Budaya }
$$


Tabel 7. Hasil Capaian

Dari tabel diatas terlihat bahwa hasil yang dicapai dalam program Teknologi Tepat Guna Mesin Kukus Telur Asin (MEKUTUS) adalah : 1). Efisiensi waktu pengukusan telur asin dari 4 jam menjadi 2 jam. Dengan demikian maka ada penghematan waktu dan tenaga yang dikeluarkan oleh Pak Musolin di UD Do'a Bunda pada saat produksi. 2). Tingkat panas yang dihasilkan oleh MEKUTUS merata karena berbahan dari stainless steel dan menggunakan kontrol suhu serta dilengkapi cerobong pembuangan untuk menjaga tekanan didalam ruang pemasak telur tetap stabil. 3). Dengan demikian maka ada peningkataan produktivitas telur asin kukus yang pada akhirnya meningkatkan omzet penjualan telur asin kukus pada mitra UD Do'a Bunda. Pada tabel dibawah ini terlihat peningkatan omzet 520,81 \% ketika di bulan Mei - Juli menggunakan MEKUTUS. 4). Tingkat K3 (Keamanan dan Keselamatan Kerja) meningkat lebih baik karena pada MEKUTUS terdapat solenoid valve yang mengatur flow $L P G$ pada interval suhu $70^{\circ} \mathrm{C}-90^{\circ} \mathrm{C}$ sehingga potensi terjadi kelebihan pemakaian bahan bakar diminimalisir serta terdapat cerobong pembuangan untuk menjaga tekanan didalam ruang pemasak telur tetap stabil. 5). Hasil telur asin kukus yang diproduksi MEKUTUS semakin berkualitas seperti tampak di gambar bawah ini.

\section{KESIMPULAN}

Dari rangkaian kegiatan yang dilakukan maka dapat dirumuskan kesimpulan sebagai berikut : 1).Mitra UKM dapat meningkatkan produktivitas untuk pengukusan telur dengan Teknologi Tepat Guna MEKUTUS, 2). Mitra UKM dapat memiliki efisiensi waktu untuk pengukusan telur asin kukus Teknologi Tepat Guna MEKUTUS, 3). Dengan adanya buku pedoman penggunaan alat dan perawatan alat serta buku pedoman viral marketing : mitra mampu menggunakan alat, cara merawat alat dan cara mengatasi problem ketika alat ada kendala serta penggunaan viral marketing setiap harinya, 4).

\begin{tabular}{clll}
\hline No & Keterangan & Konvesional & \multicolumn{1}{c}{ Mekutus } \\
\hline 1 & Waktu & 4 jam & 2 jam \\
2 & Kalor & $\begin{array}{l}\text { Tidak } \\
\text { Merata }\end{array}$ & Merata \\
& & $\begin{array}{l}\text { Tidak } \\
\text { Merata }\end{array}$ & Merata \\
3 & Kematangan & Tanpa & Menggunakan \\
4 & Otomasi & Meningkat \\
& Produktivitas & - & $520,81 \%$ \\
& & Tidak & Terjamin \\
6 & K3 & Terjamin & Penghematan \\
& & Pemborosan & LPG \\
& Efek & LPG & Desain \\
9 & Model & Panci & Terstruktur \\
& & Kukusan & SOP dan viral \\
10 & Lain-lain & - & marketing \\
\hline
\end{tabular}

Adanya peningkatan omzet sebesar 173,6 \% per bulan dengan adanya Teknologi Tepat Guna MEKUTUS dan penggunaan viral marketing.

\section{UCAPAN TERIMAKASIH}

Dalam penulisan pengabdian ini mendapat bantuan dari banyak pihak, kami menyampaikan rasa terimakasih sebesar-besarnya kepada : 1). Kementerian Riset, Teknologi dan Pendidikan Tinggi atas dukungannya melalui hibah Program Kreativitas Mahasiswa 2). Rektor Universitas Wijaya Putra Bapak H. Budi Endarto,SH., M.Hum. atas segala sarana dan fasilitas yang diberikan kepada kami hingga penyelesaian program pengabdian sesuai dengan waktu yang telah ditentukan 3). Dr. Soenarmi, SE., MM. selaku Dekan Fakultas Ekonomi dan Bisnis Universitas Wijaya Putra yang telah memberikan dukungan penulisan dan memberi izin untuk melakukan penelitian dan observasi Bapak Musholin pemilik UD Doa Bunda sebagai mitra pengabdian 4). Dr. C. Sri Hartati, SE., MM Ketua Program Studi Magister Manajemen Universitas Wijaya Putra Surabaya yang telah memberikan dukungan penulisan dalam penulisan 5). Segenap teman-teman Komunitas Penalaran Universitas Wijaya Putra yang telah membantu penulis dalam pengambilan data 6). Terima kasih juga kami sampaikan kepada penyelengara atas kesempatannya untuk bergabung dalam Konferensi Nasional ke 5 PKM-CSR tahun 2019. 


\section{REFERENSI}

Novia, D., S. Melia, N. Z. Ayuza. (2011). Kajian Suhu Pengovenan Terhadap Kadar Protein Dan Nilai Organoleptik Telur Asin Jurnal Peternakan Vol 8 (70 - 76) No 2 September 2011.

Putra, Agfianto Eko. (2002). "Belajar Mikrokontroler AT89C51/52/55 (Teori dan Aplikasi. Edisi pertama”. Yogyakarta : Gava Media. Andini,Natasya Putri.

Suharyono, Sunarti., (2014). Pengaruh Viral Marketing Terhadap Kepercayaan Pelanggan dan keputusan pembelian (studi Pada Mahasiswa Fakultas Ilmu Administrasi Universitas Brawijaya 2013 yang Melakukan Pembelian Online Melalui Bisnis (JAB) Vol. 11 No. 1 Juni 2014 
Prosiding PKM-CSR, Vol. 2 (2019)

e-ISSN: 2655-3570

Ekonomi, Sosial, dan Budaya 